\title{
The Metabolism of 2-Oxogluconate by Pseudomonas aeruginosa
}

\author{
By BARBARA K. ROBERTS, M. MIDGLEY AND E. A. DAWES \\ Department of Biochemistry, University of Hull, \\ Kingston upon Hull, $\mathrm{HU} 6{ }_{7} \mathrm{RX}$
}

(Received 6 April I973; revised I4 May 1973)

\begin{abstract}
SUMMARY
The 2-oxogluconate kinase and 2-oxogluconate 6-phosphate reductase of Pseudomonas aeruginosa were purified approx. I00-fold. The activities of these enzymes, and a 2-oxogluconate transport system, were induced when the organism was grown on glucose, gluconate or 2-oxogluconate but were absent when the organism was grown on glycerol, succinate or citrate. Gluconate dehydrogenase is membrane-bound and acts extracellularly.
\end{abstract}

\section{INTRODUCTION}

The ability of a variety of micro-organisms to grow on 2-oxogluconate as sole carbon and energy source was demonstrated by De Ley \& Vandamme (I955). De Ley (1954) had previously shown that Aerobacter cloacae converts 2-oxogluconate by an ATP-dependent kinase [EC, 2.7. I.63] to the corresponding 6-phosphate ester which is then reduced by 2-oxo-6-phosphogluconate reductase [EC. I. I. I.69] to 6-phosphogluconate. The kinase and reductase have also been demonstrated in $A$. aerogenes (Frampton \& Wood, 1961 $a$ ), Pseudomonas fluorescens (Frampton \& Wood, 196I $b$ ) and Leuconostoc mesenteroides (Cifferri \& Blakely, 1959).

Although Pseudomonas aeruginosa can grow on 2-oxogluconate, the precise pathway of its metabolism in this organism has not been defined, other than a chromatographic demonstration of an ATP-dependent production of 2-oxogluconate 6-phosphate (De Ley $\&$ Vandamme, 1955). We have therefore investigated the roles of the kinase and reductase enzymes and measured their specific activities in extracts of the organism grown on various carbon sources including glucose and gluconate.

Pseudomonas aeruginosa possesses parallel pathways of glucose and gluconate catabolism that converge at 6-phosphogluconate (Fig. I), the non-phosphorylative (direct oxidative) and phosphorylative pathways respectively. We have previously shown (Midgley \& Dawes, 1973) that glucose dehydrogenase, the first enzyme of the non-phosphorylative pathway, acts extracellularly. We now report that the second enzyme of this sequence, gluconate dehydrogenase, also acts extracellularly and thus, when growing on glucose or gluconate the organism produces 2-oxogluconate in the medium by the extracellular activity of these enzymes.

\section{METHODS}

Organism. The organism used was Pseudomonas aeruginosa, strain PAO, kindly provided by Professor B. W. Holloway. Previous work in this laboratory has used $P$. aeruginosa $2 \mathrm{~F} 32$ and the major features of regulation of glucose catabolism reported with this strain (Hamilton \& Dawes, 1959, I960, 196I; Hamlin, Ng \& Dawes, 1967; Ng \& Dawes, 1967, 


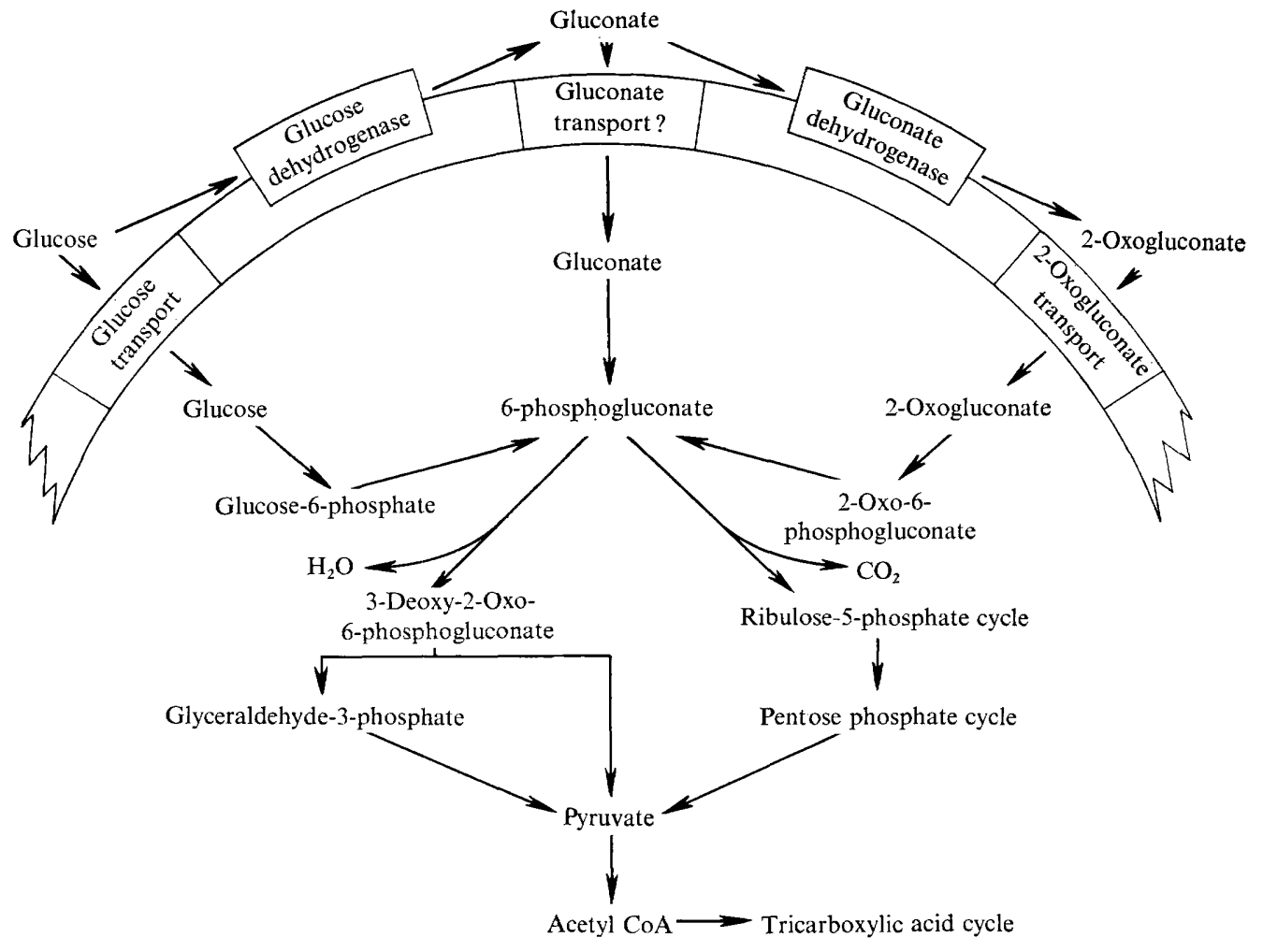

Fig. I. Enzymes and transport systems involved in the catabolism of glucose by Pseudomonas aeruginosa.

I973; Midgley, I972; Midgley \& Dawes, I973) have now been confirmed with strain PAO (P. H. Whiting, M. Midgley \& E. A. Dawes, unpublished observations).

Growth and maintenance of cultures. Routine maintenance of cultures, growth of the organisms for determination of enzyme specific activities, harvesting and preparation of bacterial extracts were as previously described (Ng \& Dawes, I973; Midgley \& Dawes, 1973). Large (20 1) batch cultures were grown in a fermenter operated with an air flow of $51 / \mathrm{min}$ at $37^{\circ} \mathrm{C}$ and with $\mathrm{pH}$ controlled to $7 \cdot \mathrm{I}$.

Preparation of bacterial extracts. Bacterial extracts, for fractionation into membrane and soluble components, were prepared with a French pressure cell (Milner, Lawrence \& French, I950) operated at $27.6 \mathrm{MN} . \mathrm{m}^{-2}$ or by a technique employing carbenicillin and cycloserine to produce osmotically fragile cells, which were then lysed by exposure to hypotonic medium. Bacteria in mid-exponential phase in gluconate minimal medium $(50 \mathrm{ml})$, were diluted, at $37^{\circ} \mathrm{C}$, with $200 \mathrm{ml}$ of medium containing sucrose $(50 \mathrm{~g})$, carbenicillin $(200 \mathrm{mg})$, cycloserine $(20 \mathrm{mg})$, sodium gluconate $(2.5 \mathrm{~g})$ and $\mathrm{MgSO}_{4} .7 \mathrm{H}_{2} \mathrm{O}(0.74 \mathrm{~g})$, made up in the nutrient yeast broth medium of Isaac \& Holloway (I968). After incubation for 6 to $8 \mathrm{~h}$ at least 50 to $70 \%$ of the population showed deformed morphology when examined microscopically. The bacteria were harvested by centrifuging at $23000 \mathrm{~g}$ for $5 \mathrm{~min}$ and resuspended in $\mathrm{Mg}^{2+}$-glycylglycine buffer ( $18 \mathrm{ml}$ of $120 \mathrm{mM}$-buffer, $\mathrm{pH} 7 \cdot \mathrm{I}$, plus $2 \mathrm{ml}$ of $0 . \mathrm{I} \mathrm{M}-\mathrm{MgSO}_{4}$ ). DNase (approximately $50 \mu \mathrm{g}$ ) was added to the viscous solution which was incubated at $37^{\circ} \mathrm{C}$ until free-flowing. Intact bacteria were removed by centrifuging twice at $9000 \mathrm{~g}$ for 
$5 \mathrm{~min}$ at $0{ }^{\circ} \mathrm{C}$. The bacterial extract was then fractionated by centrifuging at $25000 \mathrm{~g}$ for $\mathrm{I} \mathrm{h}$. The pellet was resuspended in the original volume of $\mathrm{Mg}^{2+}$-glycylglycine buffer and recentrifuged as before. The washed pellet was resuspended in $\mathrm{Mg}^{2+}$-glycylglycine buffer at a density of 0.1 to $0.2 \mathrm{mg}$ protein $/ \mathrm{ml}$. Extracts prepared with the French Press were fractionated by ultracentrifuging as previously described (Midgley \& Dawes, 1973).

The assay of enzymes of 2-oxogluconate metabolism. De Ley \& Vandamme (1955) demonstrated qualitatively an ATP-dependent production of 2-oxogluconate 6-phosphate in extracts prepared from Pseudomonas aeruginosa. We were initially concerned with developing a quantitative assay for this kinase which could be used to determine specific activities in crude bacterial extracts containing various interfering enzymes, such as high ATPase activity, that made the results of indirect assays (e.g. those based on acid production) inaccurate. Preliminary experiments in which 2-oxogluconate 6-phosphate was generated in situ from 2-oxogluconate and ATP revealed that 2-oxogluconate 6-phosphate reductase could use NADPH. As crude extracts possessed only low NADPH oxidase activity, accurate assays could be obtained by coupling the kinase and reductase activities, especially if partially purified preparations of the two enzymes, showing no cross-contamination, were available. The assay described by Brown \& Romano (1969), though inapplicable for accurate studies with crude extracts because of high ATPase and high NADH oxidase activity, was used initially to follow the course of kinase purification. Once partially purified kinase preparations were available, they were used to locate reductase-containing fractions and so permitted assessment of reductase purification. The following assay systems, in which either excess reductase or excess kinase was added were devised: tris- $\mathrm{HCl}$ buffer (I $20 \mathrm{~mm}, \mathrm{pH} 7.5$ ), I ml; $\mathrm{MgCl}_{2}$ (0.6 M), 0.I ml; NADPH (2 mM), ०.I ml; ATP (36 mM, pH 7.5), 0.3 ml; partially purified 2-oxogluconate 6-phosphate reductase, $2 \cdot \mathrm{I}$ units; Na-2oxogluconate $(50 \mathrm{~mm}), 0 . \mathrm{I} \mathrm{ml}$; bacterial extract, $0.1 \mathrm{ml}$; and water to $3 \mathrm{ml}$. 2-Oxogluconate 6 -phosphate reductase was assayed in a similar reaction mixture except that partially purified 2-oxogluconate kinase $(2 \cdot 2$ units) replaced the reductase. All other enzymes were assayed as described by $\mathrm{Ng} \&$ Dawes (1973) except that gluconate dehydrogenase was assayed in the presence of phenazine methosulphate ( $2 \mathrm{~mm}$ final concentration). All assays were conducted at $37^{\circ} \mathrm{C}$ and corrected for endogenous activity. Specific activities are expressed as $\mu \mathrm{mol} / \mathrm{h} / \mathrm{mg}$ protein. One unit of enzyme is defined as the amount of enzyme which will catalyse the conversion of $x \mu \mathrm{mol}$ of substrate $/ \mathrm{h}$ at $37^{\circ} \mathrm{C}$.

Enzyme purification. Operations were conducted at $4{ }^{\circ} \mathrm{C}$. Bacterial extracts, prepared by sonication (Midgley \& Dawes, I973) of suspensions of Pseudomonas aeruginosa strain PAO harvested from 201 of gluconate medium, were treated with $20 \%(\mathrm{v} / \mathrm{v})$ protamine sulphate $(20 \mathrm{mg} / \mathrm{ml})$ and the precipitate discarded. To the supernatant ammonium sulphate was added to $20 \%$ saturation, the precipitate was recovered and dissolved in EDTA $\left(\mathrm{IO}^{-3} \mathrm{M}\right.$, $\mathrm{pH} 7 \cdot 6$ ). This solution was adjusted to $\mathrm{pH} 6 \cdot 0$ with $\mathrm{I} \mathrm{M}-\mathrm{NaOH}$ and applied to a DEAEcellulose column $(25 \times 2.5 \mathrm{~cm})$. The column was washed with $65 \mathrm{ml}$ of $0.06 \mathrm{M}$-phosphate buffer $\left(\mathrm{IO}^{-3} \mathrm{M}\right.$ with respect to EDTA, $\mathrm{pH} \mathrm{6}{ }^{\circ}$ ). This was followed by gradient elution with $100 \mathrm{ml} 0.06 \mathrm{M}$-phosphate buffer in the mixing chamber and $300 \mathrm{ml} 0.12 \mathrm{M}$-phosphate buffer in the reservoir, both $0.005 \mathrm{M}$ with respect to EDTA and $\mathrm{pH} 6 \cdot 7$.

Fractions (IO ml) were collected and assayed for 2-oxogluconate kinase and 2-oxogluconate 6-phosphate reductase. The fractions containing kinase were pooled and the kinase precipitated with ammonium sulphate (30\% saturation) and redissolved in $5 \mathrm{ml}$ EDTA $\left(\mathrm{IO}^{-3} \mathrm{M}, \mathrm{pH} 7 \cdot 6\right)$. Similarly the reductase was precipitated with $20 \%$ ammonium sulphate.

Characterization of the 2-oxogluconate kinase fraction. Purified kinase $(2 \cdot 2$ units $)$ was in- 
cubated in the assay system developed, except that NADPH and purified reductase were omitted. After 90 min incubation the reaction was terminated by the addition of ethanol $(2 \mathrm{ml})$, precipitated protein removed by centrifuging and the concentration of 2-oxo compounds of the supernatant was determined.

Characterization of the 2-oxogluconate 6-phosphate reductase fraction. Purified reductase (2 units) was incubated in the assay system developed, with the addition of purified kinase $\left(2 \cdot 2\right.$ units) and NADPH $(4 \mu \mathrm{mol})$. After $2 \mathrm{~h}$ incubation at $37{ }^{\circ} \mathrm{C}$, when $E_{340}$ measurements indicated that the NADPH had been consumed, the reaction mixture was deproteinized by the addition of ethanol $(2 \mathrm{ml})$, centrifuged, and the supernatant assayed for content of 2-oxo compounds.

Transport studies. These were performed with radioactive substrates and washed bacterial suspensions in the presence of chloramphenicol, as described by Midgley \& Dawes (1973). Organisms were separated from the suspending medium by rapid filtration and subsequently washed with $\mathrm{Mg}^{2+}(\mathrm{O} \cdot \mathrm{I} \%$, w/v)-phosphate $(0.067 \mathrm{M})$ buffer, $\mathrm{pH} 7 \cdot \mathrm{I}$, containing $2 \%(\mathrm{w} / \mathrm{v})$ $\mathrm{NaCl}$, a concentration of $\mathrm{NaCl}$ found necessary to overcome the effect of temperature shock on organisms of Pseudomonas aeruginosa strain PAO.

Radiochemical techniques. The assay of radioactivity in samples from transport studies, and on electrophoretograms or chromatograms, was as described by Midgley \& Dawes (1973).

Separation methods. Electrophoresis was carried out with either (i) 50 mm-sodium borate ( $\mathrm{pH} 9 \cdot 0$ ) or (ii) $25 \mathrm{~mm}$-glycine/sodium citrate buffer $\left(\mathrm{pH} \mathrm{x}^{\cdot 5}\right)$ on a Shandon high-voltage electrophoresis apparatus operated at $4 \mathrm{kV}$ for 30 to $60 \mathrm{~min}$. The following chromatographic solvent systems were employed: solvent system I, pyridine:butanol: $\mathrm{H}_{2} \mathrm{O}$ (I : I : I by vol.), descending; and solvent system 2, pyridine: $\mathrm{NH}_{4} \mathrm{OH}$ (sp.gr. 0.88$): \mathrm{H}_{2} \mathrm{O}(6: 2: \mathrm{I}$, by vol.), descending. All separations were effected on Whatman no. I paper. Marker compounds were made visible by the methods of Midgley \& Dawes (I973).

Preparation of 2-oxo $\left[{ }^{14} \mathrm{C}\right]$ gluconate. This substrate was prepared enzymatically in Warburg manometers from $\left[{ }^{14} \mathrm{C}\right]$ gluconate $(3.4 \mathrm{mCi} / \mathrm{mmol}$, Radiochemical Centre, Amersham, Buckinghamshire) using a crude bacterial extract prepared from gluconate-grown organisms. The manometer flasks contained in the main compartment: bacterial extract $(20 \mathrm{mg}$ protein $/ \mathrm{ml}$ ), $1.5 \mathrm{ml}$; water, $0.8 \mathrm{ml}$; and in the side arm: sodium gluconate, $10.9 \mu \mathrm{mol}$ in $0.5 \mathrm{ml}$, or $0.5 \mathrm{ml}$ of water (for measuring the endogenous rate of oxygen consumption). The centre well contained a roll of Whatman no. 54I filter paper and $0.2 \mathrm{ml}$ of $20 \%(\mathrm{w} / \mathrm{v}) \mathrm{KOH}$. Oxygen uptake was followed for $6 \mathrm{~h}$, after which period the endogenous and reaction flasks showed the same rates. The reaction mixture was deproteinized by the addition of $\mathrm{I} \cdot 5 \mathrm{M}$ $\mathrm{HClO}_{4}$ ( $\mathrm{I} \mathrm{ml}$ ) and centrifuged. The supernatant was neutralized with a solution containing (final concentrations) $\mathrm{KOH}(5 \mathrm{M})$, EDTA $(0.4 \mathrm{M})$, imidazole buffer (I M) and the precipitate removed by further centrifugation at $0^{\circ} \mathrm{C}$. The solution was then concentrated to $\mathrm{I} \mathrm{ml}$ by rotary evaporation under reduced pressure at $40^{\circ} \mathrm{C}$ and applied as a streak on to a chromatogram that was then developed in solvent system I for $46 \mathrm{~h}$. Appropriate markers of gluconate and 2-oxogluconate were also applied. After drying the chromatogram the 2 -oxo $\left[{ }^{14} \mathrm{C}\right]-$ gluconate was eluted from the appropriate areas. Preliminary electrophoresis of this material in system (i) revealed contamination with gluconate, to the extent of $5 \%$. This gluconate was removed by electrophoresis with system (i) of all the material derived from the chromatogram. 2-Oxogluconate was eluted from the electrophoretogram with water $(20 \mathrm{ml})$. Incubation of suitable samples of this material, to which unlabelled gluconate $(0 \cdot 36 \mu \mathrm{mol})$ was added as a carrier, with gluconokinase followed by electrophoresis of a sample of the reaction mixture using system (ii), failed to detect any radioactive gluconate 6-phosphate. 
Table I. Purification of 2-oxogluconate kinase and 2-oxogluconate 6-phosphate reductase

\begin{tabular}{|c|c|c|c|c|c|}
\hline & \multirow{2}{*}{$\begin{array}{c}\text { Bacterial } \\
\text { extract }\end{array}$} & \multirow{2}{*}{$\begin{array}{l}\text { Supernatant } \\
\text { from } \\
\text { protamine } \\
\text { sulphate } \\
\text { precipitation }\end{array}$} & \multirow{2}{*}{$\begin{array}{l}\mathrm{O}-20 \% \\
\left(\mathrm{NH}_{4}\right)_{2} \mathrm{SO}_{4} \\
\text { precipitate }\end{array}$} & \multicolumn{2}{|c|}{$\begin{array}{c}\left(\mathrm{NH}_{4}\right)_{2} \mathrm{SO}_{4} \text { precipitate from } \\
\text { pooled DEAE-cellulose } \\
\text { column eluate }\end{array}$} \\
\hline & & & & Kinase & Reductase \\
\hline Volume (ml) & 160 & I 82 & 25 & 5 & 5 \\
\hline Total protein $(\mathrm{mg})$ & 2320 & I 300 & 60 & $I \cdot 0$ & $\mathrm{I} \cdot \mathbf{I}$ \\
\hline \multicolumn{6}{|l|}{ Total units } \\
\hline Kinase & 2157 & I99I & 775 & 103 & $一$ \\
\hline Reductase & 1995 & I $86 \mathrm{I}$ & 636 & 一 & IIO \\
\hline Specific activity & 0.93 & $y \cdot 52$ & I $2 \cdot 9 \mathrm{I}$ & I03 & - \\
\hline ( $\mu \mathrm{mol} / \mathrm{h} / \mathrm{mg}$ protein) & 0.86 & $1 \cdot 42$ & 10.60 & 一 & 96 \\
\hline \multicolumn{6}{|l|}{ Recovery $(\%)$} \\
\hline Kinase & 100 & 93 & 36 & $4 \cdot 7$ & 一 \\
\hline Reductase & 100 & 93 & 32 & 一 & $5 \cdot 5$ \\
\hline \multicolumn{6}{|l|}{ Purification } \\
\hline Kinase & - & $I \cdot 64$ & $13 \cdot 8$ & I I I O O & 一 \\
\hline Reductase & - & $1 \cdot 68$ & I $2 \cdot 4$ & - & I I 2:0 \\
\hline
\end{tabular}

Control experiments demonstrated that under the conditions employed there was full recovery of added gluconate.

Chemicals. Calcium 2-oxogluconate was obtained from Sigma Chemical Co., St Louis, Missouri, U.S.A. and converted to its sodium salt by treatment with Dowex $50\left(\mathrm{H}^{+}\right.$form) followed by subsequent neutralization with Io $\mathrm{M}-\mathrm{NaOH}$. Cycloserine was also supplied by Sigma. Carbenicillin was obtained from Beecham Research Laboratories, Brentford, Middlesex.

Analyses. Protein was determined by either the biuret reagent (Gornall, Bardawill \& David, I949) or the method of Lowry, Rosebrough, Farr \& Randall (I95I). 2-Oxogluconate was determined as described by Lanning \& Cohen (I95I). Gluconate was determined with gluconokinase and 6-phosphogluconate dehydrogenase, purchased from Boehringer und Soehne (Mannheim, Germany) and used as described in their handbook.

\section{RESULTS}

The enzymes of 2-oxogluconate metabolism. Preliminary experiments demonstrated the presence of 2-oxogluconate kinase and 2-oxogluconate 6-phosphate reductase in extracts prepared from Pseudomonas aeruginosa grown either on 2-oxogluconate or gluconate. The purification of these enzymes is described in the Methods section and Table I. DEAEcellulose chromatography effectively separated the two activities (Fig. 2) and yielded approximately 100-fold purified enzymes. Since the transformations that these fractions catalyse, when incubated with either 2-oxogluconate plus ATP or 2-oxogluconate 6-phosphate plus NADPH, are critical for any interpretation of the data obtained by their use, the reactions were characterized.

Characterization of the 2-oxogluconate kinase fraction. Fig. 3(a) shows an electrophoretogram of the products after incubation of partially-purified 2-oxogluconate kinase with 2-oxo $\left[{ }^{14} \mathrm{C}\right]$ gluconate and ATP. The compound at the origin was unchanged 2-oxogluconate while the second compound detected, which accounted for approximately $50 \%$ of the applied radioactivity, had the mobility of a hexose phosphate. Quantitative recovery of 


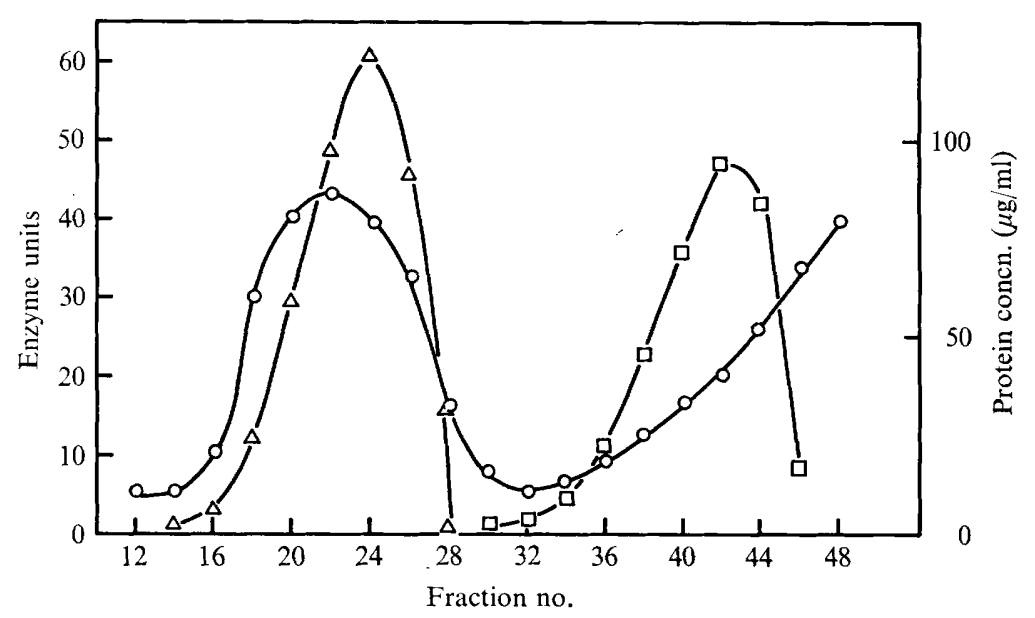

Fig. 2. Separation of 2-oxogluconate kinase and 2-oxogluconate 6-phosphate reductase by DEAE-cellulose chromatography. The procedure described in Methods and Table I was followed. O, Protein; $\square$, 2-oxogluconate kinase activity; $\triangle$, 2-oxogluconate 6-phosphate reductase activity.
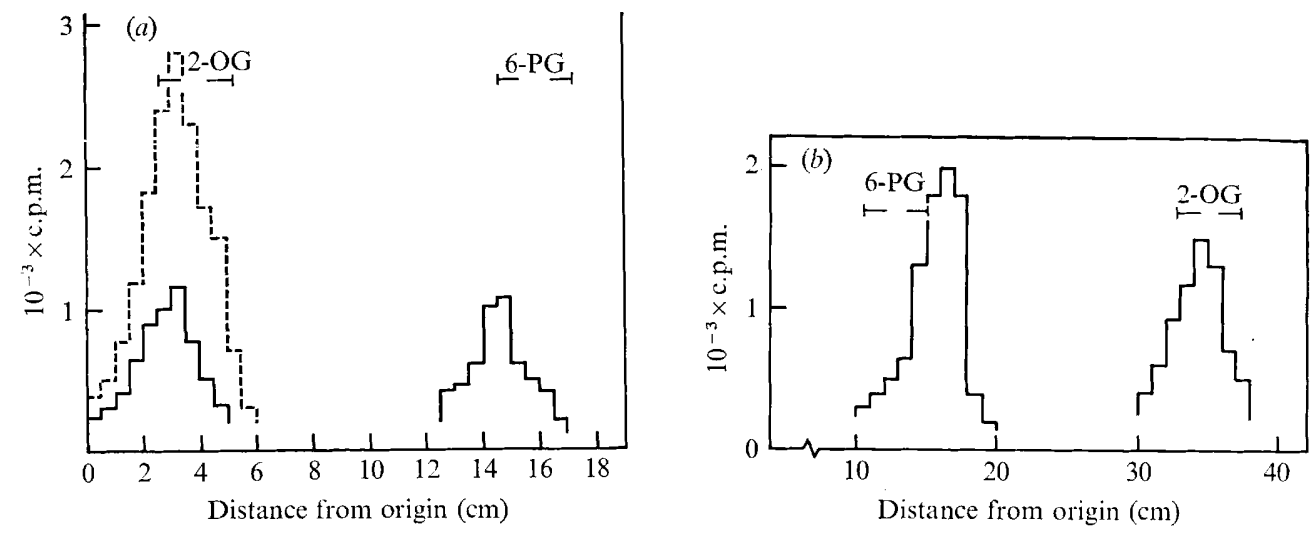

Fig. 3. (a) Electrophoresis of 2-oxogluconate kinase reaction mixture. Purified kinase (2-2 units) was incubated with ATP and 2-oxogluconate as described in Methods, except that 2 -oxo[ $\left[{ }^{14} \mathrm{C}\right] \mathrm{glu}$ conate ( $5 \mathrm{~mm}$ final concn., $0^{\circ} \mathrm{I} \mu \mathrm{Ci} / \mu \mathrm{mol}$ ) was used. The reaction was terminated with ethanol after incubation for $90 \mathrm{~min}$ at $37^{\circ} \mathrm{C}$. Electrophoresis was carried out with buffer system (ii). - - , Reaction terminated at zero time; - - reaction terminated after $90 \mathrm{~min}$. 6PG, 6-phosphogluconate; 2-OG, 2-oxogluconate.

(b) Chromatography of 2-oxogluconate kinase reaction mixture. The procedure described in the legend to Fig. $3(a)$ was followed except that the incubation period was 30 min. Solvent system 2 was used.

applied radioactivity was recorded. Chromatography of a similar reaction mixture demonstrated that a compound with a mobility similar to 6-phosphogluconate was produced (Fig. $3 b$ ). This compound was employed as a marker since authentic 2-oxo-6-phosphogluconate was not available. The compound produced, however, was not 6-phosphogluconate since there was no disappearance of the '2-oxo' function after 90 min incubation under phosphorylating conditions. The addition of 6-phosphogluconate dehydrogenase and NADP to an incubation mixture in which the kinase had been allowed to act did not produce any increase in $E_{340}$, though addition of authentic 6-phosphogluconate did. The production 
of the phosphorylated derivative was ATP-dependent, and there was no contamination of the preparation with reductase activity.

Characterization of 2-oxogluconate 6-phosphate reductase fraction. Purified 2-oxogluconate kinase was used to generate 2-oxogluconate 6-phosphate in situ. The product of the reductase activity was characterized as 6-phosphogluconate by the observation that the ' 2 -oxo' function disappeared stoichiometrically with concomitant NADPH consumption and the demonstration that the product was a substrate for 6-phosphogluconate dehydrogenase. With the techniques described in Methods (when $5 \mu \mathrm{mol}$ of 2-oxogluconate, ATP and purified kinase were incubated with $4 \mu \mathrm{mol}$ of NADPH), when all the NADPH was oxidized, $0.6 \mu \mathrm{mol}$ of ' 2 -oxo' function remained. That the reduced product was a substrate for 6phosphogluconate dehydrogenase was shown by the addition of 6-phosphogluconate dehydrogenase to the reductase assay system, after reaction (to the extent of $80 \%$ ) had been allowed to occur; an immediate increase in $E_{340}$ was recorded. The absence of 2-oxogluconate kinase from this fraction was demonstrated by incubation with 2-oxogluconate, ATP and NADPH in the absence of added kinase, when NADPH oxidation was not observed.

Specific activities of the enzymes of 2-oxogluconate metabolism. Specific activities of these enzymes in extracts derived from bacteria grown on a variety of media are in Table 2 . The activities detected were directly proportional to the amounts of bacterial extract added to the assay system. Since we desired to relate these activities to the activities of the enzymes of the major glucose catabolic pathways, the other enzymes shown were also assayed.

Transport of 2-oxogluconate and gluconate. The ability of organisms grown on different media to transport 2-oxogluconate or gluconate was assessed by measuring the initial rate of uptake of ${ }^{14} \mathrm{C}$ substrate as Midgley \& Dawes (1973) described for glucose transport (Table 3).

The role of gluconate dehydrogenase. Midgley \& Dawes (1973) have shown that glucose dehydrogenase acts extracellularly to produce gluconate, and the possibility that gluconate dehydrogenase might act in a similar manner was important for understanding the role of the enzymes of 2-oxogluconate metabolism in this organism. A previous investigation (Campbell, Hogg \& Strasdine, 1962) suggested that the enzyme was not membrane-bound but our present studies indicate that it is, although the exact proportion that is demonstrably membrane-bound depends on the method of breakage (Table 4). The highest proportion of membrane-bound gluconate dehydrogenase was observed with membranes prepared by the carbenicillin-cycloserine procedure, and this ranged between 40 and $80 \%$ with different preparations.

That gluconate dehydrogenase acts extracellularly was established by the application of the criterion previously applied to glucose dehydrogenase activity, i.e. the rate of uptake of ${ }^{14} \mathrm{C}$ from $\left[{ }^{14} \mathrm{C}\right]$ gluconate is far less than the rate of gluconate disappearance from the medium.

The initial rate of transport was measured in duplicate over the first min of incubation, and the rate of gluconate consumption was determined with an identical incubation mixture from which samples $(0.5 \mathrm{ml})$ were removed over a 20 min period; the initial gluconate concentration was $5 \mathrm{mM}$ and the bacterial density in each case was $460 \mu \mathrm{g} / \mathrm{ml}$. The rates of ${ }^{14} \mathrm{C}$ uptake and of gluconate utilization were respectively, 30 and $440 \mu \mathrm{mol} / \mathrm{g} \mathrm{dry} \mathrm{wt} / \mathrm{min}$. The apparent $K_{m}$ (I $\mathrm{mM}$ ) of gluconate dehydrogenase, determined from a conventional double reciprocal plot, is identical with that previously measured for glucose dehydrogenase acting on glucose (Midgley \& Dawes, I973). This value was obtained with a crude bacterial extract ( $(\cdot 14 \mathrm{mg}$ protein/assay) produced by sonication of gluconate-grown organisms, and prepared as described by Midgley \& Dawes (1973). 
Table 2. Assay of enzymes of 2-oxogluconate metabolism of Pseudomonas aeruginosa PAO grown on various carbon sources

The pairs of figures are the values obtained with independently derived bacterial extracts.

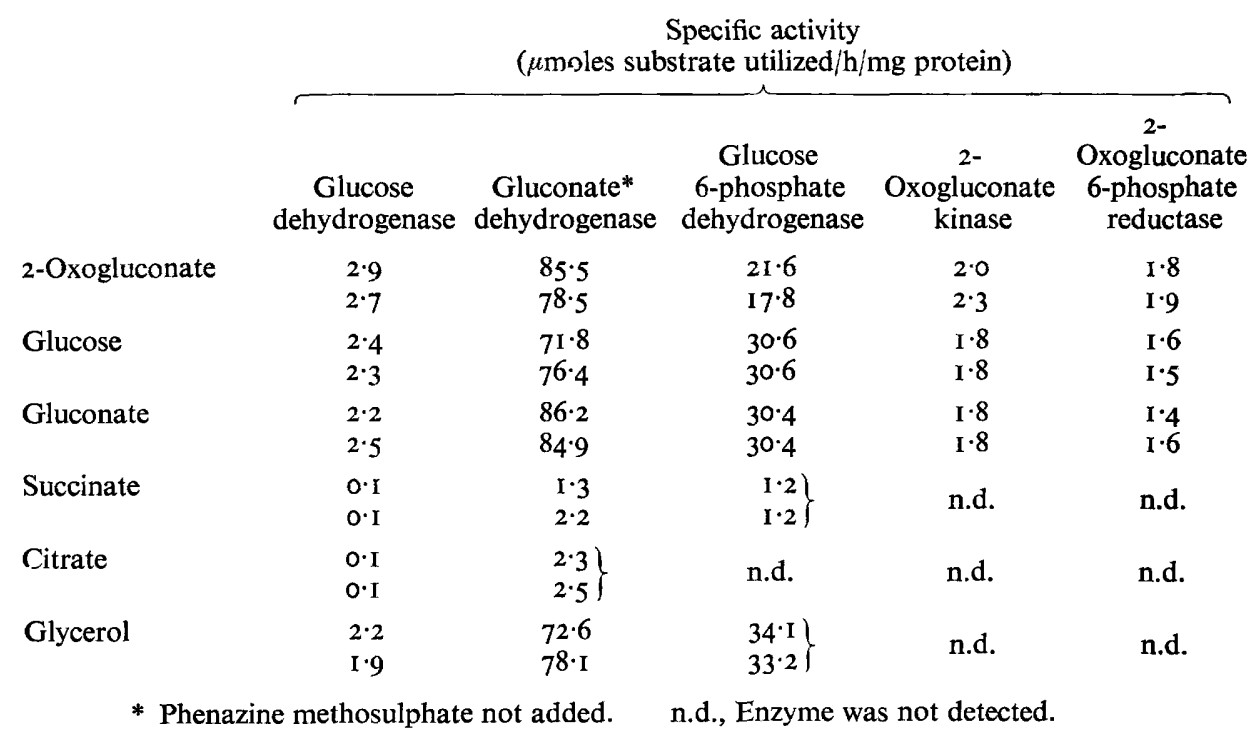

Table 3. Transport of 2-oxogluconate and gluconate by

Pseudomonas aeruginosa PAO grown on various carbon sources

Transport rate was measured over the first min after the addition of substrate (2-oxogluconate I $\mathrm{mm}$ final concentration, specific activity $0.1 \mu \mathrm{Ci} / \mu \mathrm{mol}$; gluconate, $5 \mathrm{~mm}$ final concn, $0.3 \mu \mathrm{Ci} / \mu \mathrm{mol}$ ) from four samples taken during this period. The values are the averages of duplicate determinations in which there was less than $10 \%$ variation. Different bacterial suspensions were used for each determination. The rate was linear over the period of measurement in every case.

$\begin{array}{lcc}\text { Growth } & \begin{array}{c}\left.\text { Uptake of }{ }^{14} \mathrm{C}\right] \text { substrate } \\ (\mu \mathrm{mol} / \mathrm{min} / \mathrm{g} \text { dry wt })\end{array} \\ \text { substrate } & \begin{array}{c}2- \\ \text { Oxogluconate }\end{array} & \text { Gluconate } \\ \text { 2-Oxogluconate } & 37 \cdot 5 & \text { n.p. } \\ \text { Glucose } & \text { I8. } & 48 \\ \text { Gluconate } & 36 \cdot 3 & 45 \\ \text { Citrate } & \text { n.d. } & \text { n.d. } \\ \text { Glycerol } & \text { n.d. } & 53\end{array}$

n.d., Not detected; n.p., not performed.

\section{DISCUSSION}

Our results show that 2-oxogluconate is metabolized by the route shown in Fig. I. Confirmation that this represents the sole pathway of 2-oxogluconate dissimilation awaits the isolation of mutants unable to grow on this compound and an analysis of their enzyme defect. Specific activities similar to those recorded here for the kinase have been demonstrated for the kinase of Pseudomonas fluorescens (Narrod \& Wood, 1956). 
Table 4. Comparison of the effect of different methods of bacterial breakage on the amount of membrane-bound gluconate dehydrogenase obtained

\begin{tabular}{|c|c|c|c|c|c|}
\hline \multirow[b]{2}{*}{$\begin{array}{l}\text { Method of producing } \\
\text { cell extract }\end{array}$} & \multicolumn{2}{|c|}{ Crude extract } & \multicolumn{3}{|c|}{ Units of enzyme present } \\
\hline & $\begin{array}{l}\text { Specific* } \\
\text { activity }\end{array}$ & $\begin{array}{l}\text { Total } \\
\text { units }\end{array}$ & Supernatant & Pellet & $\begin{array}{c}\text { Washed } \\
\text { pellet }\end{array}$ \\
\hline Sonication & 380 & 16500 & $12600^{\dagger}$ & 一 & 4000 \\
\hline French press & 330 & 26800 & $24000 \dagger$ & - & 4400 \\
\hline Penicillin-cycloserine & 54 & 340 & $128 t$ & I94 & 176 \\
\hline
\end{tabular}

The kinase and reductase enzymes, and also 2-oxogluconate transport, are present when the organism grows on glucose or gluconate. The role of these enzymes under such conditions is clarified by the demonstration that the two enzymes of the non-phosphorylative pathway, glucose and gluconate dehydrogenases, act extracellularly, thus generating 2-oxogluconate. When the organism grows on glucose the amount of glucose carbon committed to the phosphorylative pathway is presumably determined by the activity of the transport systems for glucose and gluconate. We have previously characterized the glucose transport system (Midgley \& Dawes, 1973) but our evidence for the existence of a unique gluconate transport system at present is based upon the observation that glycerol-grown Pseudomonas aeruginosa can transport $\left[{ }^{14} \mathrm{C}\right]$ gluconate in the presence of chloroamphenicol (Table 3 ). Table 2 reveals that glycerol-grown organisms possess neither the enzymes of 2-oxogluconate metabolism nor a 2-oxogluconate transport system (Table 3), and therefore the intracellular accumulation of gluconate by such bacteria indicates a means of uptake other than by extracellular conversion to 2-oxogluconate and its subsequent transport. The apparent $K_{m}$ of both enzymes of the non-phosphorylative pathway is I mM, and although the transport systems act at lower external concentrations, e.g. the $K_{m}$ for glucose uptake is $8 \mu \mathrm{M}$ (Midgley \& Dawes, 1973), the excess of these activities (I0- to 20-fold) over the transport activities is sufficient to commit a major portion of the carbon of glucose and gluconate to the nonphosphorylative pathway. Indeed, this property has allowed the isolation of mutants defective in glucose dehydrogenase, since these organisms do not now produce an acidic reaction on a suitable indicator medium (Midgley \& Dawes, 1973).

MacKechnie \& Dawes (I969) showed that Pseudomonas aeruginosa gives approximately the same molar growth yield for glucose and gluconate. If it is assumed that the extracellular conversion of glucose to gluconate yields no energy to the organism, then growth on glucose is almost equivalent to growth on gluconate since such a large proportion of glucose is converted to gluconate by glucose dehydrogenase. However, if similar assumptions are made concerning the extracellular conversion of gluconate to 2-oxogluconate it would be expected that similar molar growth yields would have been observed for these compounds. A significant difference was recorded (MacKechnie \& Dawes, I969), thus the question of whether any energy is available for these extracellular conversions remains unanswered. However, our results do offer some explanation for the apparent needless conversion of glucose and gluconate to 2-oxogluconate, which is then converted to 6-phosphogluconate, a compound which can be more directly produced from glucose and gluconate. The two pathways, phosphorylative and non-phosphorylative, are found in separate compartments, inside and outside the organism respectively.

As might be expected from previous studies concerning the regulation of the major 
glucose-catabolizing enzymes ( $\mathrm{Ng} \&$ Dawes, 1973), the enzymes of 2-oxogluconate metabolism are absent when the organism is grown on organic acids such as citrate and succinate (Table 2). These enzymes, and the 2-oxogluconate transport system, are probably controlled independently from the previously studied glucose-catabolizing enzymes since the glycerol-grown organism is unable to metabolize 2-oxogluconate and yet shows high specific activities of the glucose-catabolizing enzymes, including the enzymes of the nonphosphorylative pathway.

We are indebted to the S.R.C. for the award of a C.A.P.S. Studentship to B.K.R., and to the co-operating body, Unilever Research, Colworth House, Sharnbrook. We are also grateful to Professor G. W. Gould for his interest and support. We acknowledge the skilled technical assistance of Mr P. Reece.

\section{REFERENCES}

Brown, C. E. \& Romano, A. H. (1969). Evidence against necessary phosphorylation during hexose transport in Aspergillus nidulans. Journal of Bacteriology 100, I 198-I 203.

Campbell, J. J. R., Hogg, L. A. \& Strasdine, G. A. (1962). Enzyme distribution in Pseudomonas aeruginosa. Journal of Bacteriology 83, $1155-1160$.

CIFFERRI, O. \& BLAKELY, E. R. (I959). The metabolism of 2-keto-D-gluconate by cell-free extracts of Leuconostoc mesenteroides. Canadian Journal of Microbiology 5, 547-560.

DE LEY, J. (1954). 2-Keto-D-gluconate-6-phosphate, a new intermediate in the carbohydrate metabolism of Aerobacter cloacae. Enzymologia 17, 55-68.

De LeY, J. \& VANDAMme, J. (1955). The metabolism of sodium 2-keto-D-gluconate by micro-organisms. Journal of General Microbiology I2, I62-171.

Frampton, E. W. \& WoOD, W. A. (196I $a$ ). Purification and properties of 2-ketogluconokinase from Aerobacter aerogenes. Journal of Biological Chemistry 236, 2578-2580.

Frampton, E. W. \& WoOD, W. A. (1961 $b$ ). Carbohydrate oxidation by Pseudomonas fluorescens. Journal of Biological Chemistry 236, 2571-2577.

Gornall, A. G., Bardawill, C. J. \& DaVId, M. M. (I949). Determination of serum proteins by means of the biuret reaction. Journal of Biological Chemistry 177, 75I-766.

Hamilton, W. A. \& Dawes, E. A. (1959). A diauxic effect with Pseudomonas aeruginosa. Biochemical Journal 7I, 25P.

Hamilton, W. A. \& Dawes, E. A. (1960). The nature of the diauxic effect with glucose and organic acids in Pseudomonas aeruginosa. Biochemical Journal 76, 70 P.

Hamilton, W. A. \& Dawes, E. A. (196I). Further observations on the nature of the diauxic effect with Pseudomonas aeruginosa. Biochemical Journal 79, 25 P.

Hamlin, B. T., NG, F. M.-W. \& Dawes, E. A. (1967). Regulation of enzymes of glucose metabolism in Pseudomonas aeruginosa by citrate. Microbial Physiology and Continuous Culture. Proceedings of Third International Symposium, $2 \mathrm{I}$ I-23I.

IsaAC, J. H. \& Holloway, B. W. (I968). Control of pyrimidine biosynthesis in Pseudomonas aeruginosa. Journal of Bacteriology 96, I 732-I 741.

Lanning, M. C. \& CoHEN, S. S. (1951). The detection and estimation of 2-ketohexonic acids. Journal of Biological Chemistry 189, 109-I I4.

Lowry, O. H., Rosebrough, N. J., Farr, A. L. \& Randall, R. J. (195I). Protein measurement with the Folin phenol reagent. Journal of Biological Chemistry 193, 265-275.

MACKeCHNIE, I. \& DAWES, E. A. (I969). An evaluation of the pathways of metabolism of glucose, gluconate and 2-oxogluconate by Pseudomonas aeruginosa by measurement of molar growth yields. Journal of General Microbiology 55, 341-349.

MddGLeY, M. (1972). The transport of methyl $\alpha$-glucoside by Pseudomonas aeruginosa. Biochemical Journal I27, 50-5I P.

Midgley, M. \& Dawes, E. A. (1973). The regulation of transport of glucose and methyl $\alpha$-glucoside in Pseudomonas aeruginosa. Biochemical Journal 132, I4I-154. 
Milner, H. W., Lawrence, N. S. \& French, C. S. (1950). Colloidal dispersion of chloroplast material. Science, New York III, 633-634.

Narrod, S. A. \& Wood, W. A. (1956). Carbohydrate oxidation by Pseudomonas fluorescens. Journal of Biological Chemistry 220, 45-55.

NG, F. M.-W. \& DAwes, E. A. (1967). Regulation of enzymes of glucose metabolism by citrate in Pseudomonas aeruginosa. Biochemical Journal 104, $48 \mathrm{P}$.

NG, F. M.-W. \& DAWEs, E. A. (1973). Chemostat studies on the regulation of glucose metabolism in Pseudomonas aeruginosa by citrate. Biochemical Journal 132, I29-140. 